\title{
Mean platelet volume may not be a biomarker monitoring of brucellosis
}

Ortalama trombosit hacmi bruselloz takibinde bir biyobelirteç olmayabilir

\author{
Cengiz Beyan*, Esin Beyan
}

Department of Hematology (Prof. C. Beyan, MD), Gülhane Military Medical Academy, TR-06018 Ankara, Internal Medicine Clinic (Assoc. Prof. E. Beyan, MD), Keçiören Training and Research Hospital, TR-06280 Ankara

Geliş tarihi/Received: January 14, 2014; Kabul tarihi/Accepted: January 14, 2014

*iletişim adresi:

Dr. Cengiz Beyan, Hematoloji Bilim Dalı, Gülhane Askeri Tıp Akademisi, TR-06018 Ankara. Eposta: cengizbeyan@hotmail.com

Keywords: Biological markers, brucellosis, mean platelet volume, platelet count

Anahtar sözcükler: Biyolojik belirteçler, bruselloz, ortalama trombosit hacmi, trombosit sayıs1

To the editor

We read with great interest the research article by Kader et al. [1] entitled with evaluation of mean platelet volume (MPV) levels in brucellosis patients. They retrospectively investigated the complete blood count parameters in patients with brucellosis. They found that MPV values were statistically significantly low in pre-treatment group compared with post-treatment group and healthy controls. They suggested that MPV levels might be useful in the follow-up of brucellosis patients. We would like to comment on this study.

Firstly, MPV is not correlated with the platelet function and activation. The platelet indices including MPV are not used to assess for platelet function. The current gold standard test of platelet functions is the platelet aggregation with light transmission turbidimetric method. Beyan et al. [2] did not show any correlation between platelet indices measured including platelet count, MPV, platelet mass, platelet distribution width and plateletcrit and platelet aggregation responses with collagen, adenosine diphosphate and epinephrine obtained with light transmission turbidimetric platelet aggregometry in healthy subjects. Also, De Luca et al. [3] carried out a cohort study including 1016 diabetic patients undergoing coronary angiography and found that MPV was not related to platelet reactivity. Actually, MPV related to the platelet production (thrombopoiesis) not platelet function or activation.

It is correct that MPV is a parameter of complete blood count analysis that usually is used by clinicians; nevertheless, accurate measurements of platelet count and MPV are very important for diagnostic, therapeutic and research purposes. The correct measurement of MPV is dependent on a number of variables, including time of analysis after venipuncture, method of analysis, anticoagulant used and specimen storage temperature [4.] Ethylenediaminetetraacetic acid (EDTA) induces MPV changes with impedance technology over time. MPV increases up to $30 \%$ within 5 minutes of exposure and increases further by 10 to $15 \%$ over the next two hours [5]. Lancé et al. [6] found that timing is very important when measuring MPV and optimal measuring time with using EDTA should be 120 minutes after venipuncture. Because the study had retrospective design and the measurement times of samples were not standardized, the validity and reliability of data were doubtful.

As a result, MPV may not be a biomarker monitoring of brucellosis because of standardization troubleshoot. 


\section{References}

1. Kader C, Yolcu S, Erbay A. Evaluation of mean platelet volume (MPV) levels in brucellosis patients. Cumhuriyet Med J 2013; 35: 488-94.

2. Beyan C, Kaptan K, Ifran A. Platelet count, mean platelet volume, platelet distribution width, and plateletcrit do not correlate with optical platelet aggregation responses in healthy volunteers. J Thromb Thrombolysis 2006; 22: 161-4.

3. De Luca G, Verdoia M, Cassetti E, Schaffer A, Di Giovine G, Bertoni A, Di Vito C, Sampietro S, Aimaretti G, Bellomo G, Marino P, Sinigaglia F; Novara Atherosclerosis Study (NAS) group. Mean platelet volume is not associated with platelet reactivity and the extent of coronary artery disease in diabetic patients. Blood Coagul Fibrinolysis 2013; 24: 619-24.

4. Lancé MD, Sloep M, Henskens YM, Marcus MA. Mean platelet volume as a diagnostic marker for cardiovascular disease: drawbacks of preanalytical conditions and measuring techniques. Clin Appl Thromb Hemost 2012; 18: 5618.

5. Jackson SR, Carter JM. Platelet volume: laboratory measurement and clinical application. Blood Rev 1993; 7: 104-13.

6. Lancé MD, van Oerle R, Henskens YM, Marcus MA. Do we need time adjusted mean platelet volume measurements? Lab Hematol 2010; 16: 28-31. 